This item was submitted to Loughborough's Research Repository by the author.

Items in Figshare are protected by copyright, with all rights reserved, unless otherwise indicated.

\title{
Re-engineering through pre-assembly: client expectations and drivers
}

\section{PLEASE CITE THE PUBLISHED VERSION}

http://www.tandfonline.com/doi/abs/10.1080/09613210302000

\section{PUBLISHER}

(c) Taylor and Francis

\section{VERSION}

AM (Accepted Manuscript)

\section{LICENCE}

CC BY-NC-ND 4.0

\section{REPOSITORY RECORD}

Gibb, Alistair G.F., and Frank Isack. 2019. "Re-engineering Through Pre-assembly: Client Expectations and Drivers". figshare. https://hdl.handle.net/2134/9018. 
This item was submitted to Loughborough's Institutional Repository (https://dspace.lboro.ac.uk/) by the author and is made available under the following Creative Commons Licence conditions.

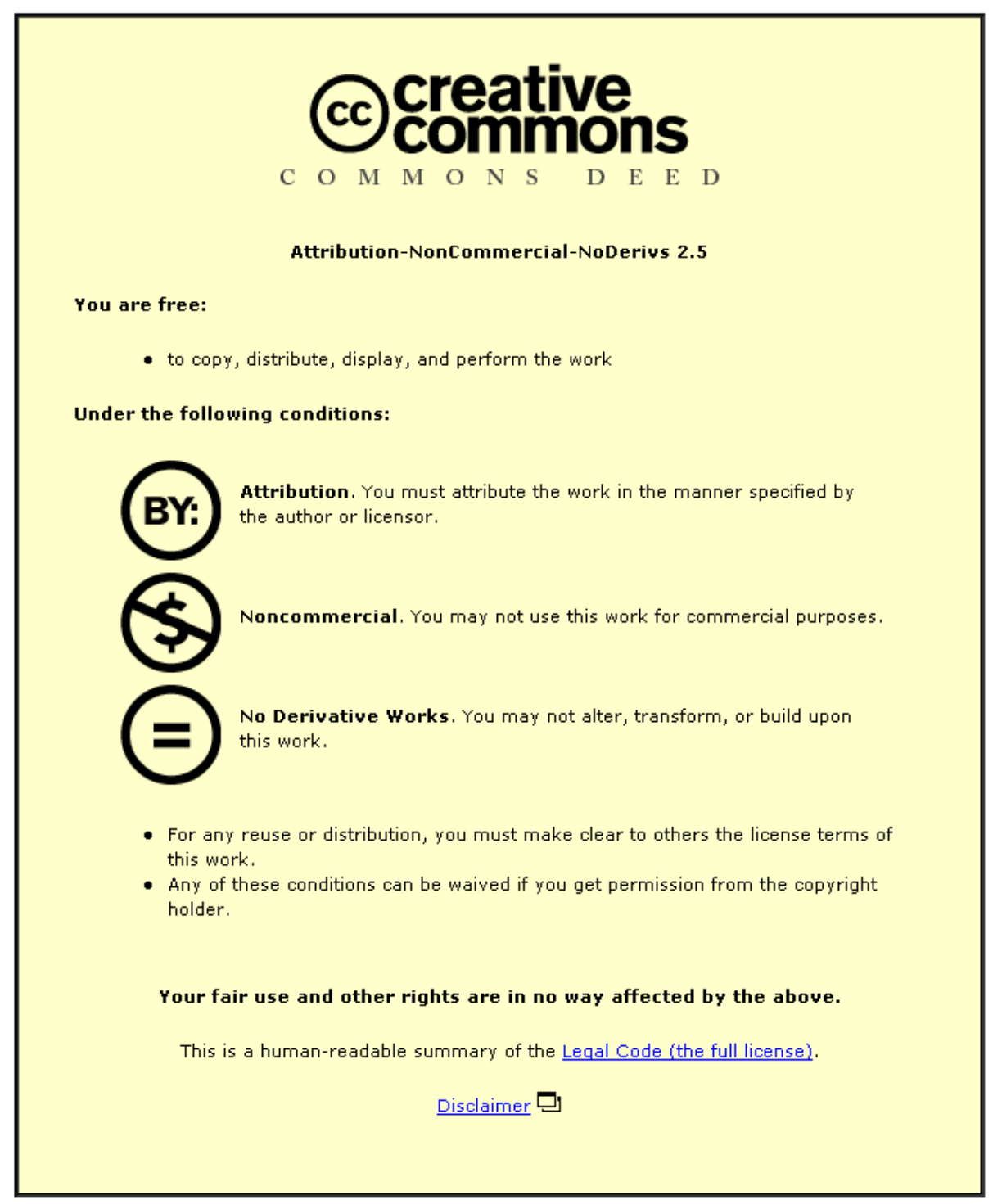

For the full text of this licence, please go to: http://creativecommons.org/licenses/by-nc-nd/2.5/ 


\title{
RE-ENGINEERING THROUGH PRE-ASSEMBLY - CLIENT EXPECTATIONS AND DRIVERS
}

\author{
Alistair G F Gibb \\ $P h D, B S c, C E n g, M I C E, M C I O B$ \\ Department of Civil \& Building Engineering \\ Loughborough University \\ a.g.gibb@lboro.ac.uk
}

\section{Frank Isack}

$P h D, M B A$

Business Consultant

Gibb, A and F. Isack (2003) Re-engineering through pre-assembly: client expectations and drivers. Building Research \& Information 31(2): 146 - 160.

Pre-assembly is an important facet of the strategy to re-engineer construction. It can be categorised as: modular building; volumetric pre-assembly, non-volumetric pre-assembly and component manufacture / sub-assembly. This paper presents the results of an interview survey of major construction clients regarding their expectations from and drivers for preassembly on their projects. In particular time, cost, quality and productivity benefits through minimisation of on-site operations and duration, less congestion on site, improved health and safety along with greater and more predictable quality are identified. To get the best out of pre-assembly, clients acknowledge that they must be able to freeze the design early, provide reasonable lead times and time for pre-site prototyping. Client's past experience has been mixed, with some citing tangible benefits, but others experiencing poor quality products and a limited and disjointed supply chain - these mitigate against efforts to increase pre-assembly as part of the re-engineering mantra. Typically, clients accepted that suppliers should be involved early, but in practice many do not re-engineer the process and leave key decisions too late in the process to maximise the benefits. More than half wanted to see an increase in the use of pre-assembly on their projects, but the supply chain must re-focus to consider the client's perspective and capitalise on this opportunity.

Whilst pre-assembly is not new and many have published on the subject, the perspective of clients has not been adequately covered. Pre-assembly may be well understood by manufacturers, contractors and even some designers, but unless the client decision makers understand its benefits and limitations then their misunderstandings and prejudices will continue to be a barrier to further development. 


\title{
RE-ENGINEERING THROUGH PRE-ASSEMBLY - CLIENT EXPECTATIONS AND DRIVERS
}

\author{
Alistair G F Gibb \& Frank Isack - Loughborough University
}

\section{Introduction}

Pre-assembly, prefabrication, modularisation, system building, and industrialised building are all terms in common use at various times over the last century. Pre-assembly is seen as one of the tenets of improving construction in the $21^{\text {st }}$ century by its inclusion in the UK Government sponsored report Re-thinking Construction (Egan, 1998). The UK government acknowledges that construction must be re-engineered and that "a much greater emphasis on off-site assembly was one of the key ingredients to changing the construction culture to retain and recruit talent and at the same time deliver improvements in performance required by increasingly demanding clients (clients)" (Raynsford, 2000).

The pre-assembly debate has waxed and waned for many years, with early examples many hundreds of years ago and a more focussed approach in the middle of the last century. A full discussion of the historical development of pre-assembly is outside of the scope of this paper, but has been published elsewhere (White, 1965; Russell, 1981; Herbert, 1984; Tatum et al, 1986; Groak, 1992; Gann, 1996; Gibb, 1999). The theoretical context of pre-assembly has been covered elsewhere by the authors (in particular Gibb, 2001). In the last few years there has been an increase in interest and debate with much work from organisations like CIRIA (1999 \& 2000), BSRIA (1998) and the Housing Forum (2002). For instance the Housing Forum report identifies a number of necessary actions for stakeholders if their vision of a prefabricated future is to be realised. One of the main actions is the need for the developers to 'recognise the advent of the drivers and be prepared to explore alternative methods of construction' (Housing Forum 2002).

Various publications have addressed contractors and suppliers perspectives of pre-assembly (Bottom et al, 1994; Sarja, 1998; BSRIA, 1999; CIRIA, 1997; CIRIA 1999). But, in the main the significant role of the client in the decision making process, especially for large, repeatorder clients, has been largely overlooked. The exception to this is perhaps the residential sector where the 'client' as the developer is clearly actively involved in the process.

This paper presents the need to re-engineer the process from a client perspective following interviews of fifty-nine major construction client representatives. These interviews formed part of a project in the UK by Loughborough University and Laing Technology for the Construction Industry Research and Information Association (CIRIA). The project deliverable is a client's guide and tool kit for standardisation and pre-assembly (CIRIA, 2000) currently being developed further as a CD-based software tool. The interviews covered client drivers for construction projects, process and component standardisation and pre-assembly. This paper concentrates on pre-assembly with other matters covered elsewhere (Gibb \& Isack, 2001). Using accepted qualitative research techniques, the interviewees' opinions were sought and, where appropriate, evidence was obtained to verify these views. This paper aims to present these results in an even-handed manner, believing that even if some of the interviewees may be misinformed in their view it is nevertheless important to seek to understand their opinions and preconceptions in order to move the debate forward.

\section{Pre-assembly}

Pre-assembly literally means to 'assemble-before' and covers the manufacture and assembly (usually off-site) of buildings or parts of buildings earlier than they would traditionally be 
constructed on site, and their subsequent installation into their final position. Many people have a very precise, if somewhat incomplete, picture of what pre-assembly means. They often equate pre-assembly with full modular building techniques, where the units form the actual structure and fabric of the building. However, pre-assembly can be sub-divided into four categories based on increasing amounts of pre-assembly:

- component manufacture and sub-assembly

- non-volumetric pre-assembly

- volumetric pre-assembly

- modular building

Figure 1 presents these categories along with definitions, sub-categories, typical materials and examples (taken from a major building context). This figure was developed by the author in a state of the art report for CRISP (Construction Research \& Innovation Strategy Panel) (Gibb, 2001).

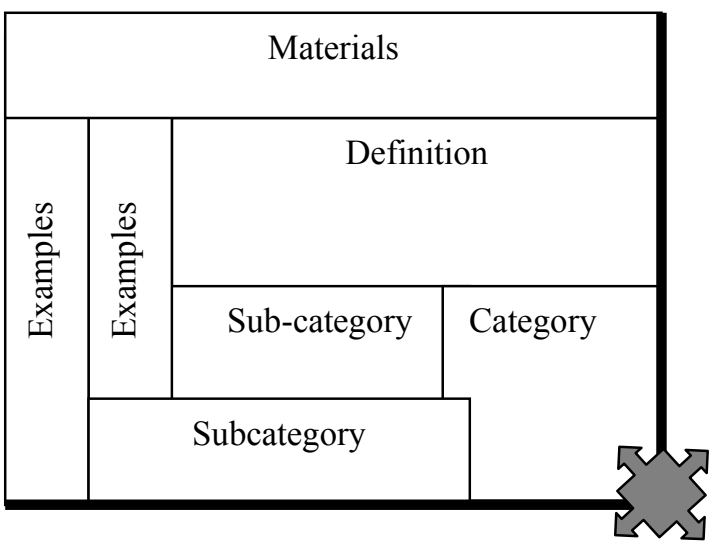

\begin{tabular}{|c|c|c|c|c|c|c|c|c|}
\hline \multicolumn{4}{|c|}{ Various materials } & \multicolumn{5}{|c|}{$\begin{array}{l}\text { Steel, precast concrete, timber, aluminium, } \\
\text { advanced composites, hybrids }\end{array}$} \\
\hline \multirow{4}{*}{ 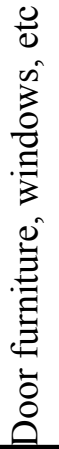 } & \multirow{3}{*}{ 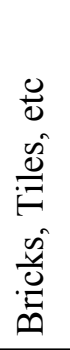 } & \multicolumn{2}{|c|}{$\begin{array}{l}\text { Items always made in a factory and } \\
\text { never considered for on-site production }\end{array}$} & \multicolumn{2}{|c|}{$\begin{array}{l}\text { Pre-assembled units which do not } \\
\text { create usable space }\end{array}$} & & & \multirow{4}{*}{ 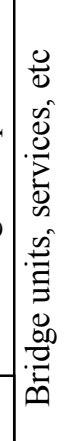 } \\
\hline & & Factory-made & \multirow{3}{*}{$\begin{array}{l}\text { Component } \\
\text { manufacture \& } \\
\text { sub-assembly } \\
\text { Level } 15\end{array}$} & \multirow{3}{*}{$\begin{array}{r}\begin{array}{r}\text { Non-volumetric } \\
\text { pre- } \\
\text { Assembly }\end{array} \\
\sqrt{\text { Level } 2}\end{array}$} & skeletal & & & \\
\hline & & & & & planar & & & \\
\hline & \multicolumn{2}{|c|}{ Sub-assemblies } & & & complex & & & \\
\hline \multirow{3}{*}{\multicolumn{2}{|c|}{ 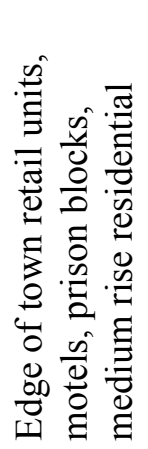 }} & Factory clad & \multirow{2}{*}{$\begin{array}{l}\text { Modular } \\
\text { Building } \\
\quad \text { Level } 3\end{array}$} & \multirow{2}{*}{$\begin{array}{l}\text { Volumetric } \\
\text { pre-assembly } \\
\text { Level } 4\end{array}$} & $\begin{array}{l}\text { Within anot } \\
\text { building }\end{array}$ & & \multirow{3}{*}{\multicolumn{2}{|c|}{ 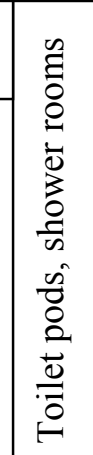 }} \\
\hline & & Clad on site & & & $\begin{array}{l}\text { Onto another } \\
\text { building }\end{array}$ & & & \\
\hline & & \multicolumn{2}{|c|}{$\begin{array}{l}\text { Pre-assembled volumetric units which } \\
\text { form the actual structure and fabric of } \\
\text { the building }\end{array}$} & \multicolumn{2}{|c|}{$\begin{array}{l}\text { Pre-assembled units which create } \\
\text { usable space and are usually fully } \\
\text { factory finished internally, installed } \\
\text { within, or onto an independent } \\
\text { structural frame }\end{array}$} & 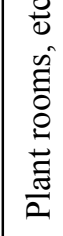 & & \\
\hline \multicolumn{4}{|c|}{$\begin{array}{l}\text { Steel frames, stressed skin plywood, precast } \\
\text { concrete, various cladding materials }\end{array}$} & \multicolumn{5}{|c|}{$\begin{array}{l}\text { Dry-lined lightweight steel frames, precast } \\
\text { concrete, advanced composites }\end{array}$} \\
\hline
\end{tabular}


Various previous reports and publications have illustrated examples of pre-assembly in construction and this is not the primary purpose of this paper. However, examples of modular buildings, volumetric and non-volumetric pre-assembled units are given (Figures $2-9$ ) to clarify the authors interpretation of the pre-assembly categories.

\section{The interviewee sample}

The fifty-nine senior personnel interviewed represented forty-two of the largest, or most frequent construction client organisations in the UK, excluding residential and engineering construction (Figure 10). Their total aggregated construction-related investment was over $£ 8 \mathrm{bn}$, almost $15 \%$ of the UK's total annual construction output.

More than half of the interviewees had individual responsibility for over 100 projects in the past five years with $80 \%$ worth between $£ 100000$ and $£ 10 \mathrm{M}$. More than two-thirds of the clients were the prime movers during the key decision making phases of the project, with around a third retaining hands-on involvement right through to construction. This clearly establishes the credibility of the interviewees and the potential of their decision-making power to re-engineer the process.

The range of pre-assembly used by respondents included: cladding systems for offices, shopping centres and incinerators; pre-cast concrete jetties; prison cells; welded piping and other structures for power stations; restaurants; service stations; toilet pods for various types of building; and, hotel bedrooms.

\section{What clients see as the benefits of pre-assembly}

Clients unprompted opinions about the benefits of using pre-assembly were categorised. Time quality and cost were the most frequently mentioned categories (Figure 11).

Time was an issue for most clients. Many would incur significant costs if they failed to meet agreed completion dates for their projects and some would benefit from the early income stream from shorter projects. Also, a shorter project time could mean less risk in terms of the market changing. Other time issues related to when contractors had access to the site, especially for airports, roads, rail and prison projects, and possible congestion caused by having too many people working in the same location at the same time.

Quality was the second most cited reason for using pre-assembly. This included obtaining better quality from factory-made products than could be achieved on site, consistency of quality and the fact that parts were more likely to be engineered to fit together correctly. Preventing the need for 'snagging' (remedial works to achieve the required standard) is one of the aims of re-engineering construction in a drive to remove waste from the process. Two respondents stated that less snagging was necessary with pre-assembly although this was a more qualitative view. Firms are only now starting to measure 'snagging' levels on their projects and how this is changing over time. Another factor that seemed important was the ability to visit the factory and see the final product before it was installed on-site.

Cost was important, especially for repeat-order clients, but many respondents noted that total cost was more important than specific elemental product cost. For example, although it might be more expensive to pre-assemble a product, other savings such as reduced preliminary costs, the absence of scaffolding, having a weather-tight building earlier and less site congestion, should be included in cost comparisons and may compensate for the 
additional 'bottom-line' cost. To achieve this requires a change in attitude and action for all construction stakeholders.

Productivity issues formed the fourth most cited category. These covered a wide range of factors including reduced site disruption, the reduction of 'wet trades' on site, being independent of on-site weather conditions and having more certainty over the control of the project. Several noted that having fewer 'wet trades' on site also helped to re-engineer the construction process. In addition, manufacturing more elements off-site resulted in less disruption on-site and this was a major factor for some clients. For example, when working in a prison, contractors have to be escorted to and from their work site and all employees have to be vetted, therefore a reduction in on-site personnel due to pre-assembly leads to cost savings for security. In the case of airports, road and rail projects, site access and working space are often restricted and pre-assembly was seen to bring additional benefits. Security issues were also important for these clients, especially at airports where all deliveries had to be inspected, for example for drugs, explosives and weapons.

Measurement of success is also one of the main strands of re-engineering. Sadly, in the survey, few respondents were able to quantify the benefits of using pre-assembly (19\%) and where information was given this was often a composite outcome from using standardised procedures as well as pre-assembly.

\section{Specific benefits cited due to pre-assembly:}

- The cost of preliminaries reduced by having shorter construction time, saving of $£ 420 \mathrm{k}$

- Shop fit-out cost and construction time reduced by $10 \%$

- Cost of aircraft pavements reduced by $18 \%$ over two years

- Unit cost of hotel bedrooms $20 \%$ lower than 10 years ago

- New fuel/service stations $15 \%$ cheaper, in real terms, than seven years ago, with more reproducible quality

- Unit cost per square metre of new restaurants reduced by $18 \%$

- Cost of prison house blocks reduced by $25 \%$

- Two expansion projects could not have been achieved without the use of pre-assembly

- Failure rate on welds reduced from $5-10 \%$ for on-site to less than $1 \%$ with off-site preassembly

\section{What clients see as the disadvantages of pre-assembly}

Where pre-assembly had not met the clients' business needs, they were asked to give reasons. The most common reply was that some products were poorly built. Several mentioned that some contractors were not experienced enough or cases where the original design for the preassembled units was incorrect. Late deliveries exacerbated by over ambitious sales team predictions were also blamed. Some believed that the application did not save money and that the same result could have been achieved by conventional methods. The volatile nature of the supply chain with some suppliers going into receivership was also cited. Two respondents had developed new pre-assembled solutions specifically for their projects. In both cases, the final cost was higher than that using conventional on-site assembly, but both are now looking for reduced costs on future projects.

Some considered that the supply base in the UK was poor with limited alternative suppliers. Many questioned the ability of suppliers to compete effectively and not just respond to clients' requests, some citing a lack of customer-focus throughout the supply chain. In this 
respect, they were looking for suppliers who could advise them on the best practices and procedures and who are actively developing products for specific market applications. They considered that it is often they, as the client, who had to devote resources to developing products to meet business needs that often resulted in project-specific 'bespoke' items. A somewhat contrary view that the supply base should consolidate was also expressed, although taken along with the previous comments, this suggests that clients see the supply base as limited in ability but also too fragmented to really respond to the challenges offered.

Several people stated that they did not have enough volume to justify looking at preassembly, considering that it was too expensive for limited repetition applications. However, others stressed that a broad perspective must be considered looking at overall project costs and not just at the specific elements.

\section{Balancing benefits and disadvantages}

To verify the previous unprompted views on benefits and disadvantages clients were asked to respond to a list of categories by stating whether the issue would cause them to use, or not to use pre-assembly (Figure 12). The data is presented to express the finding that in most cases a particular issue was a driver to choose pre-assembly for some and yet a reason not to choose it for others.

Once again time, quality and cost issues were the most frequent reasons for choosing preassembly, however some clearly had experienced problems with both quality and cost. Operational issues, cited as the main reason for not choosing pre-assembly, generally related to the perceived limitation on the operation of the building or facility being procured. Availability, as a negative, reflected the view that there were limited solutions and this could be linked to concerns about limitations on design. Safety was seen by a few as a benefit that is supported by other recent initiatives in the industry.

\section{Deciding to use pre-assembly}

Figure 13 shows the interviewees' timing for taking advice and making the decision to preassemble using project phases developed through another sector initiative, Process Protocol (Salford, 1998). The names of the project phases may change but the principles are fairly ubiquitous. The results show that $20 \%$ of clients made decisions on pre-assembly even before an actual project is defined, commissioning research to evaluate whether pre-assembly was the best way forward for them. They often made a corporate decision to use standardised systems and frequently had repeat business for the same type of project. By outline concept more than $90 \%$ of clients had taken advice but less than half had made their decision, some leaving this as late as production information. This can be compared to the optimised decision diagram developed for the CIRIA project (Figure 14) which shows the latest advised timing for decisions for modular building, volumetric and non-volumetric pre-assembly. This shows that some clients are making timely decisions, but many are leaving decisions too late to ensure that en-engineering occurs and that expected benefits are realised. 
Figure 13 Interviewees timing for preassembly (\% of 39 responses)

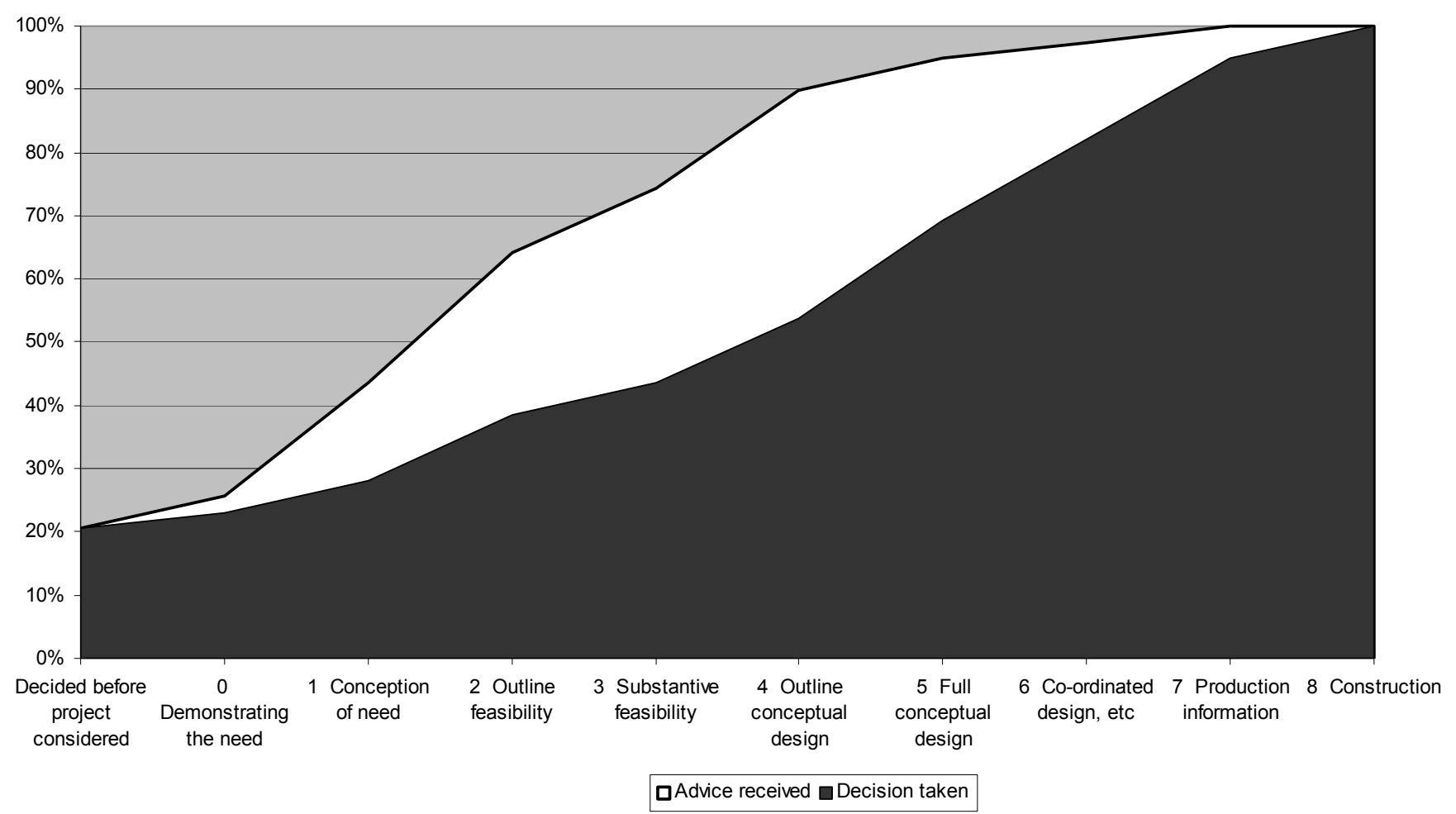

Decisions were often made by a team of people comprising the client and one or more of the professional team, architect, engineer, project manager, and sometimes contractor. Only a few firms overtly involve the supplier in this decision making process, and then as part of a team. The parties most often involved in advising on the use of pre-assembly are the client's in-house staff, the architect, or an engineering organisation. Interviewees stated that cost consultants and quantity surveyors play no role in advising on the use of these products and project managers were cited only three times. Contractors, other than as part of a team, seem to come into this process very late (co-ordinated design), although one respondent would involve the contractor from outline feasibility.

Respondents were asked how the timing of the appointment of suppliers and manufacturers affected the success or failure of the use of pre-assembly. Although there were a range of answers, most confirmed that suppliers should be on-board as early as possible, although this was not worked through on many of the client's projects. 
Figure 14 CIRIA optimised decision timing for preassembly

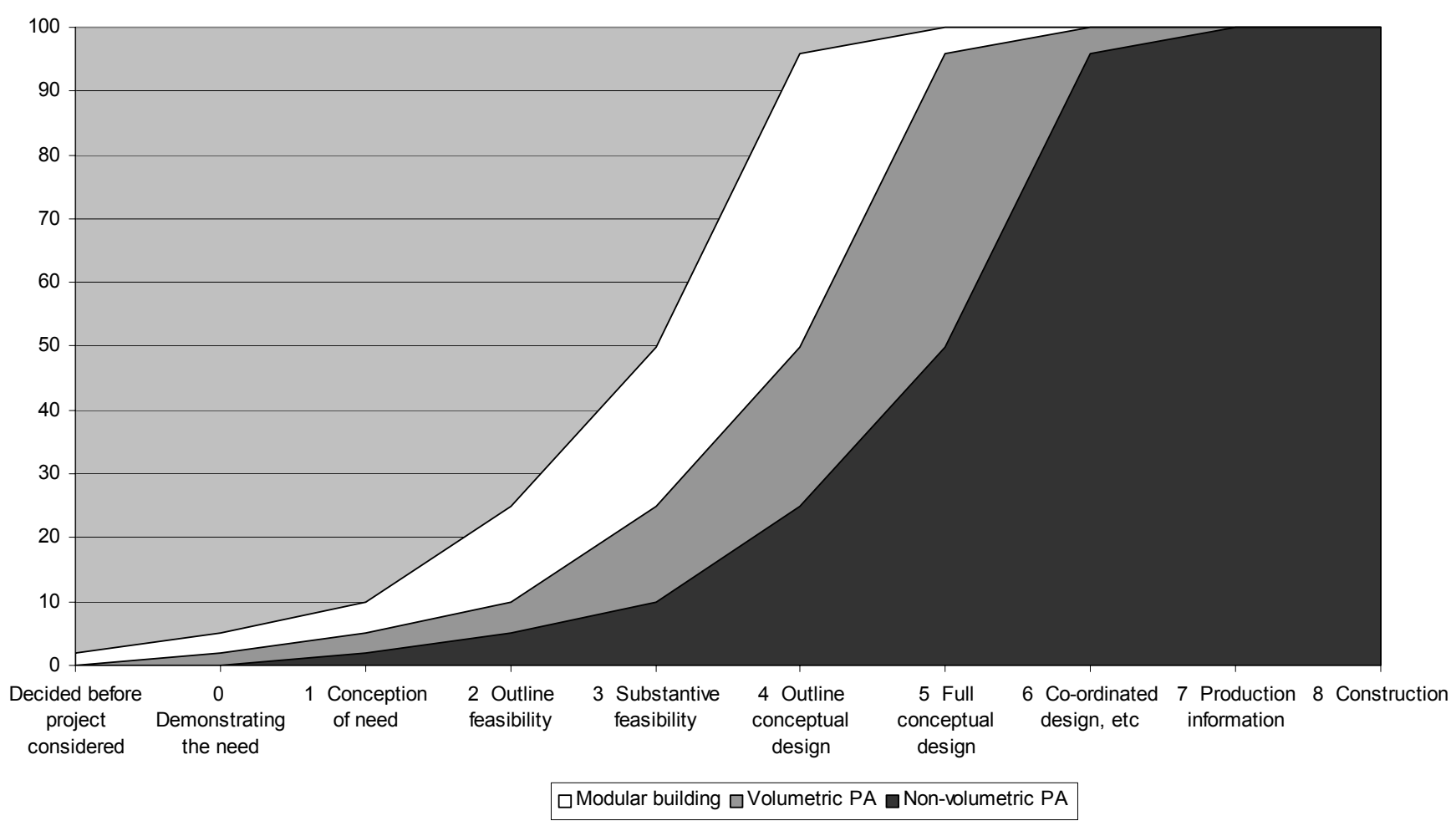

\section{Clients' expectations for the future of pre-assembly}

$52 \%$ of those interviewed would definitely use, or increase the use of pre-assembly, however, around $20 \%$ would probably not or definitely not increase pre-assembly in their projects.

This indicates inertia amongst clients against the use, or increased use of pre-assembly, despite recent initiatives and publications. Experts claim that there is a vibrant future for preassembly. The Government and industry champions hope that it will be one of the main methods of re-engineering the construction process and achieving their intended improvements in time cost, quality and health\& safety. Innovations elsewhere (e.g. virtual prototyping) may allow more flexibility in pre-assembled solutions than was previously economical. However, none of these will be realised unless the problem of client inertia is addressed along with the perceived or real concerns that clients hold to.

\section{Validation of interview data}

Using the principles of grounded theory (Fellows \& Lui, 1997), the data generated from the interviews was evaluated along with information from the extensive literature review. As a result, a list of key benefits from pre-assembly was drawn up. This was then verified by the interviewee sample that was asked to rank the importance of each benefit and the likelihood of realising the benefit. A Likert scale was used with scoring based on Saaty's analytic hierarchy process (Saaty, 1987; Lee et al, 1999) (much (9), some (3), little (1) and none (0)). The overall rating was obtained by taking the square root of the product of the importance and the likelihood. This method is presented in Figure 15 and the results are shown in Figure 16. The standard deviation for each benefit is shown on the bar indicating the level of agreement through the sample. 
A similar list was compiled for the key requirements necessary to ensure that the benefits are realised. Here the Likert scale related only to importance and the results are shown in Figure 17. 


\section{Conclusions}

Pre-assembly has an important role to play in the drive to re-engineer construction. Clients are influential in the decisions to use pre-assembly in construction projects. They have various preconceptions about pre-assembly and had a variety of past experiences, both positive and negative. They agree that there are a number of key benefits to help them achieve their business needs (Figure 15). However, there are also a number of requirements that must be met in order to realise these benefits (Figure 16). Measurement of project success or failure is very limited and must be improved if pre-assembly use is to be optimised and re-engineering is to be achieved. More than half of clients considered that there should be an increase in the use of pre-assembly in construction, but, if pre-assembly is actually going to increase the inertia against change must be faced and other players in the supply chain must consider the client perspective and seek to address their concerns. 


\section{References}

1 Bottom, D, Gann, D., Groàk, S. \& Meikle, J. Innovation in Japanese prefabricated house-building industries, Construction Industry Research and Information Association, London, 1994.

2 BSRIA Prefabrication and pre-assembly - applying the techniques to building engineering services, Compiled by Wilson, D.G.; Smith, D.H. \& Deal, J. The Building Services Research and Information Association, Bracknell, ACT 1/99, ISBN 086022505 4, 1999.

3 CIRIA Snapshot-Standardisation and Pre-assembly, Compiled by Gibb, A.G.F.; Groák, S. \& Sparksman, W.G., Construction Industry Research and Information Association, London, 1997.

4 CIRIA Adding value to construction projects through standardisation and preassembly, Compiled by Gibb, A.G.F.; Groák, S.; Neale, R.H. \& Sparksman, W.G., 1999, Construction Industry Research and Information Association, London, Report R176, ISBN 086017498 0, 1999.

5 CIRIA Client's Guide and Toolkit for optimising standardisation and pre-assembly in construction, Principal author Gibb, A.G.F., Construction Industry Research and Information Association, London, Report CP/75, ISBN 0860 175448, 2000.

6 Egan, J. Re-thinking construction, DETR, London, 1998.

7 Fellows, R. \& Lui, A. Research methods for construction, Blackwell Science, Oxford, ISBN 063204244 3, 1997.

8 Gann, D.M. Construction as a manufacturing process? - Similarities and differences between industrialised housing and car production in Japan, Construction Management and Economics, 14, 437-450, 1996.

9 Gibb A.G.F. Pre-assembly in construction: a review of recent and current industry and research initiatives on pre-assembly in construction, CRISP Report, 00/19, Construction Research \& Innovation Strategy Panel

10 Gibb A.G.F. \& Isack F. Client drivers for construction projects: implications for standardisation, ECAM - Engineering Construction and Architectural Management, Blackwell Science, February 2001, Vol. 8, No. 1, pp. 46-58, ISSN 09699988.

11 Gibb, A.G.F. Off-site fabrication - Pre-assembly, prefabrication \& modularisation, Whittles Publishing Services, Caithness, ISBN 187032577 X, 1999.

12 Gibb, A.G.F., Standardisation and pre-assembly - distinguishing myth from reality, Invited Paper, Construction Management \& Economics, April 2001, Vol. 19, pp. 307-315, Taylor \& Francis, ISSN 0144-6193.

13 Groák, S. The idea of building, E \& FN Spon / Routledge, London, ISBN 0419 17830 9, 1992.

14 Herbert, G The dream of the factory-made house: Walter Gropius and Konrad Wachsmann, MIT Press, Cambridge, Mass, ISBN 026208 1407, 1984.

15 Housing Forum, Homing in on excellence - a commentary on the use of offsite fabrication methods for the UK housebuilding industry, London, 79 pp. 2002.

16 Lee, M., Pham, H. \& Zhang, X.A. Methodology for priority setting with application to software development process, European Journal of Operational Research, 118, 1999.

17 Raynsford, N. Rethinking Construction - Profiting from Innovation, Keynote presentation, Movement for Innovation Conference, Birmingham NEC, April, www.m4i.org.uk/conference/conf speech.html, 2000.

18 Russell, B. Building systems, industrialisation and architecture, Wiley, New York, ISBN 0471279 528, 1981.

19 Saaty, R. W. The analytic hierarchy process: what it is and how it is used, 
Mathematical Modeling, 9, No. 3-5, 161-176, 1987.

20 Salford Process Protocol - Generic Design and Construction Process, University of Salford, 1998.

21 Sarja, A. (ed) Open and industrialised building, E \& FN Spon / Routledge, London, ISBN 041923840 9, 1998.

22 Tatum, C.B., Vanegas, J.A. \& Williams, J.M. Constructability improvement using prefabrication, pre-assembly and modularization, Technical Report No. 297, November 1986, Construction Industry Institute, Stanford University.

23 White, R. Prefabrication: A history of its development in Great Britain, National Building Studies Special Report 36, HMSO, London, 1965. 


\section{Captions for figures}

Figure 1 Four categories of pre-assembly, definitions, sub-categories, examples and main materials

Figure 2 Modular building - Manufacture of precast concrete units for Fazakerley Prison Courtesy of Precast Cellular Structures Ltd.

Figure 3 Modular building - Installation of steel framed unit for McDonald's Restuarants Courtesy of Yorkon Ltd.

Figure 4 Modular building - Site delivery of steel framed, double hotel bedroom unit Courtesy of Yorkon Ltd.

Figure 5 Volumetric pre-assembly - Installation of steel framed toilet unit in a restrictedspace refurbishment project (inset: toilet internals completed off-site)

Courtesy Struik and Hamerslag International $b v$.

Figure 6 Volumetric pre-assembly - Installation of precast concrete shower room unit Courtesy of Amec

Figure 7 Non-volumetric pre-assembly (planar) - Precast concrete cladding panel Courtesy of Trent Concrete Ltd.

Figure 8 Non-volumetric pre-assembly (complex) - Building services module for office ceiling zone

Courtesy of Crown House Engineering

Figure 9 Non-volumetric pre-assembly (complex) - Precast concrete bridge caissons Courtesy of Laing

Figure 10 Breakdown of companies interviewed by construction market

Figure 11 Clients' views on the benefits of pre-assembly (unprompted)

(117 responses)

Figure 12 Reasons for using, or not using pre-assembly (Prompted answers - number of times mentioned)

Figure 13 Interviewees timing for pre-assembly (Information received / Decision taken)

Figure 14 CIRIA optimised decision timing for pre-assembly

Figure 15 Verification method

Figure 16 Verified ratings of benefits from pre-assembly (Standard deviations shown on bars)

Figure 17 Verified ratings of key requirements to realise benefits from pre-assembly 



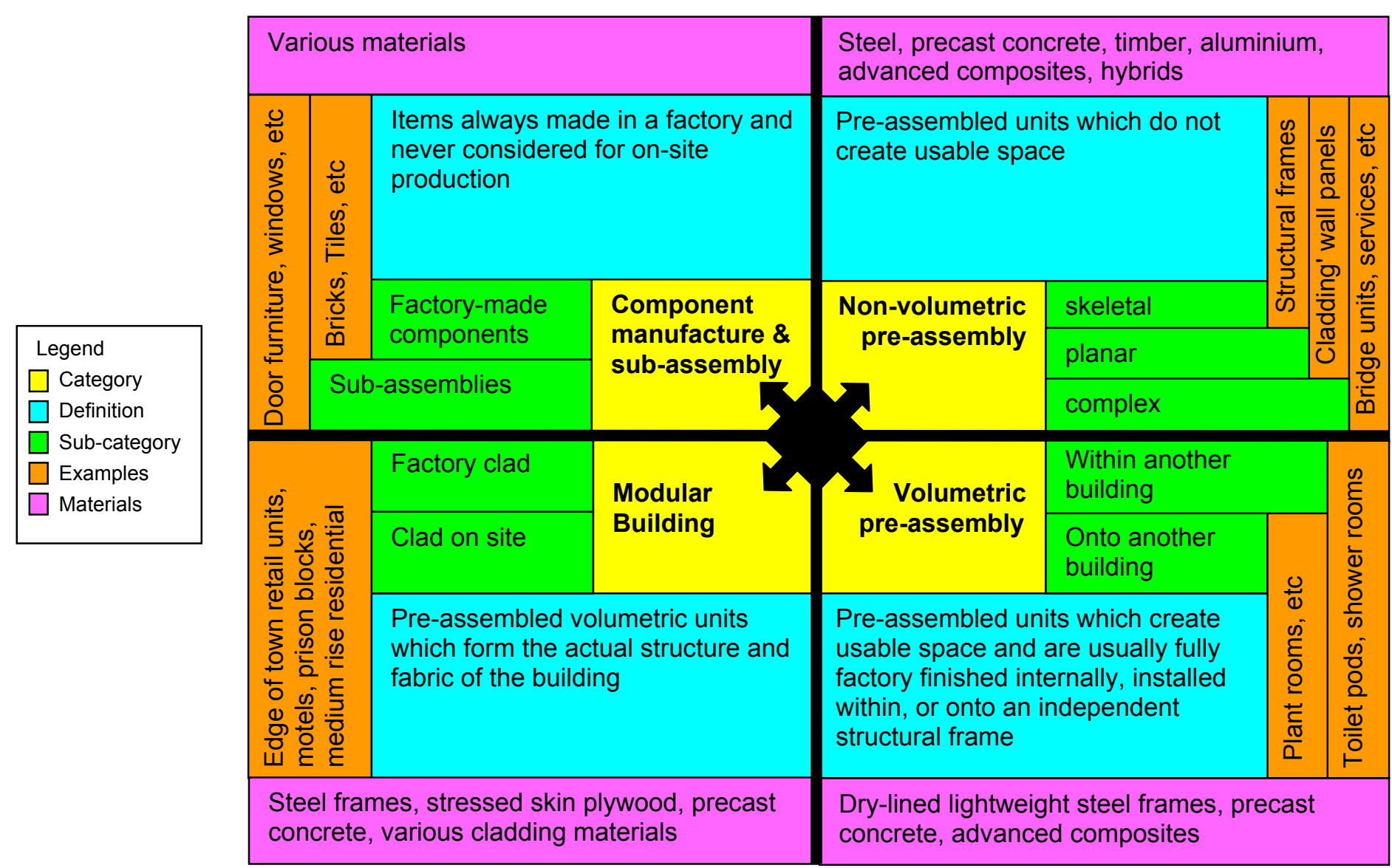

Figure 1 Four categories of pre-assembly, definitions, sub-categories, examples and main materials 
Figure 2

Modular building - Manufacture of precast concrete units for Fazakerley Prison Courtesy of Precast Cellular Structures Ltd.

\section{Caption:}

Precast concrete units formed each prison cell and were stacked on site to form the whole building. Brick cladding and tiled roofing were added on site. The manufacturers also developed a cell solution that was fully fitted out internally prior to installation.

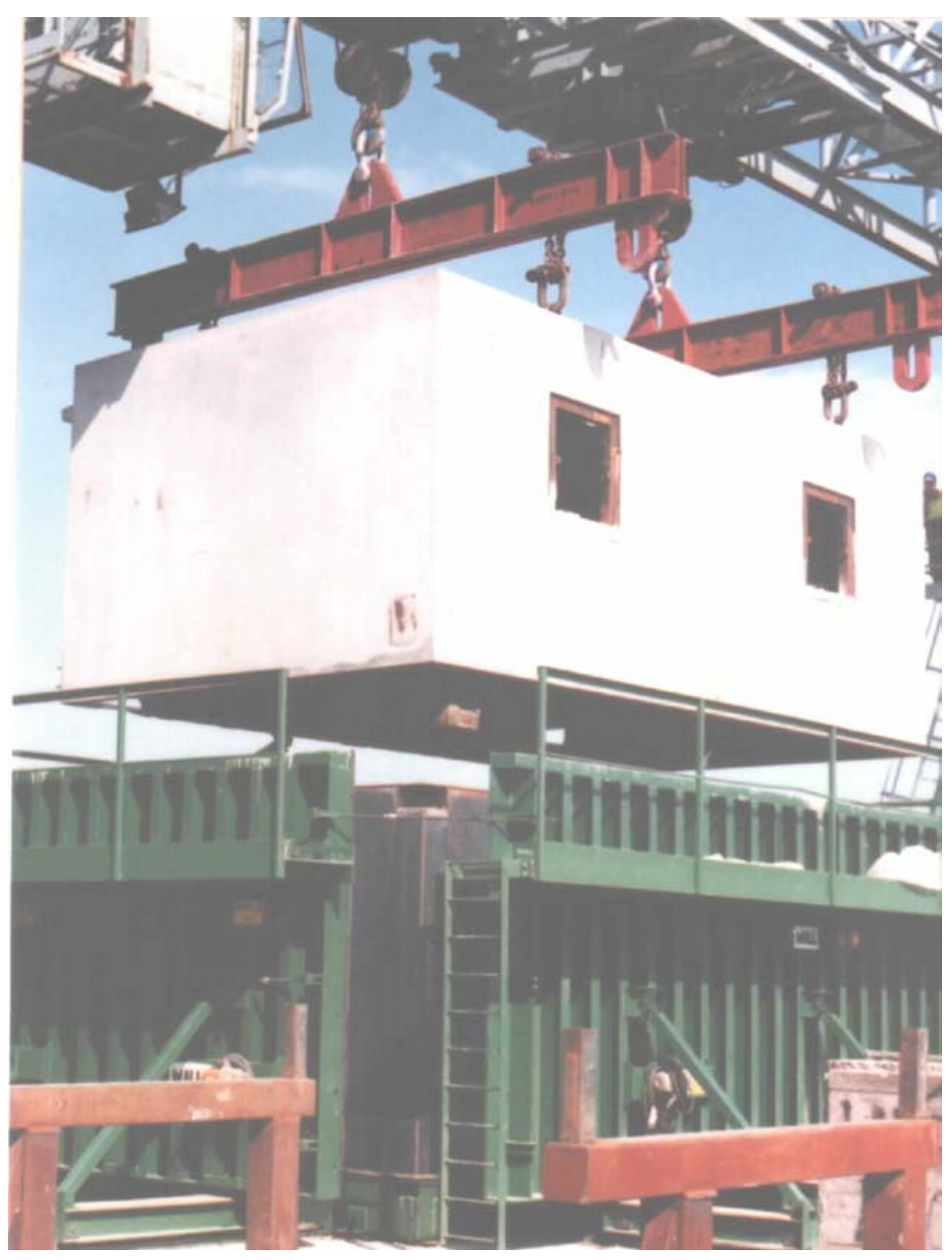


Figure 3

Modular building - Installation of steel-framed unit for McDonald's Restaurants

Courtesy of Yorkon Ltd.

\section{Caption:}

McDonald's had a very clear driver for pre-assembly, namely to reduce the time from site occupation to delivering burgers to the absolute minimum. They now measure this period in days rather than weeks or months. These modular units were assembled and fully fitted out internally and externally in the factory before being brought to site for installation and were a major factor in cutting site times.

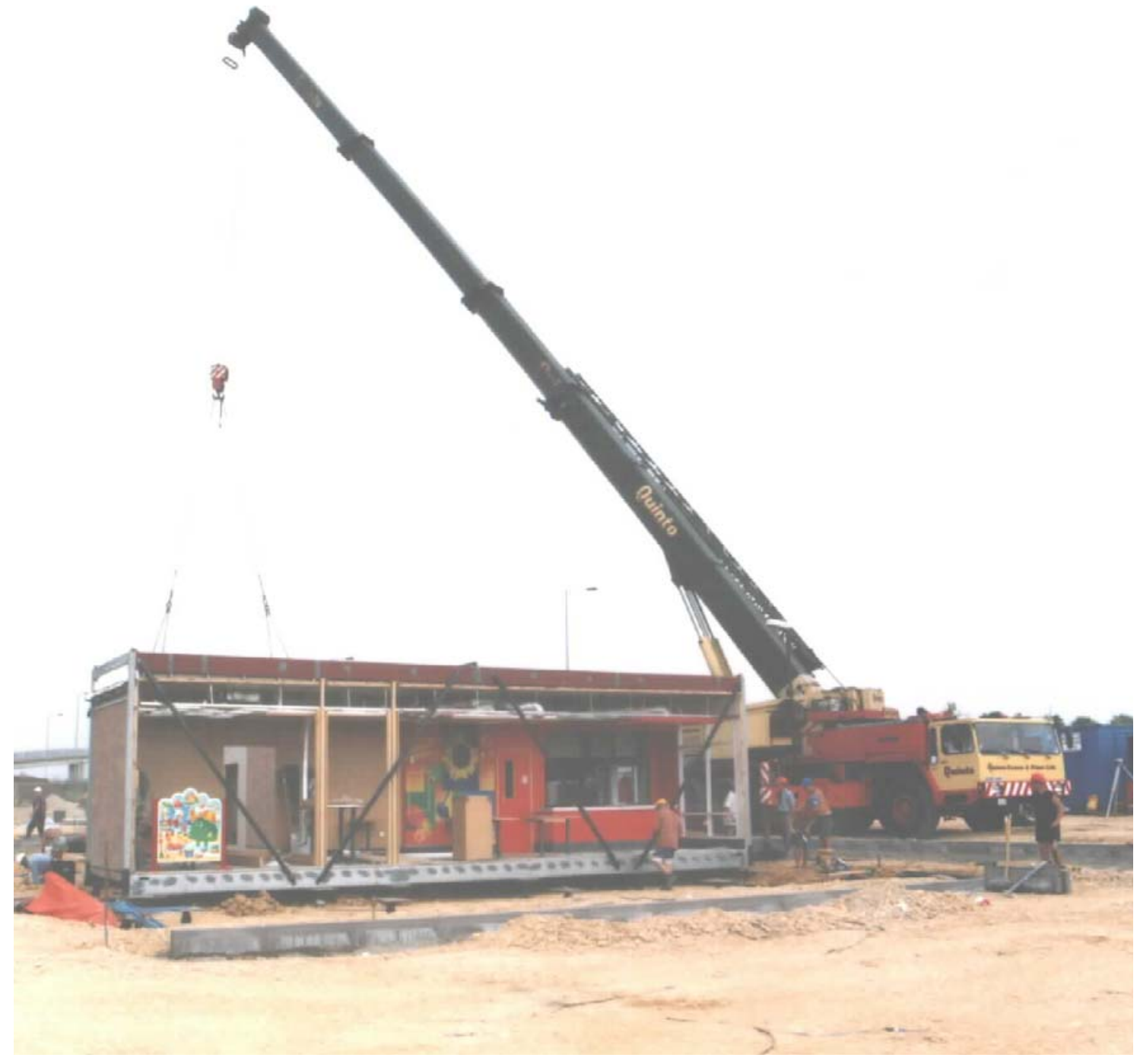


Figure 4

Modular building - Site delivery of

steel-framed, double hotel bedroom unit

Courtesy of Yorkon Ltd.

\section{Caption:}

Edge of town or out of town hotels frequently use modular building techniques. This unit includes two fully-fitted out bedrooms (complete with furniture and fittings) and also incorporates the central corridor. Units are installed on site then services connections made, corridors finished internally, brick cladding and roofing added.

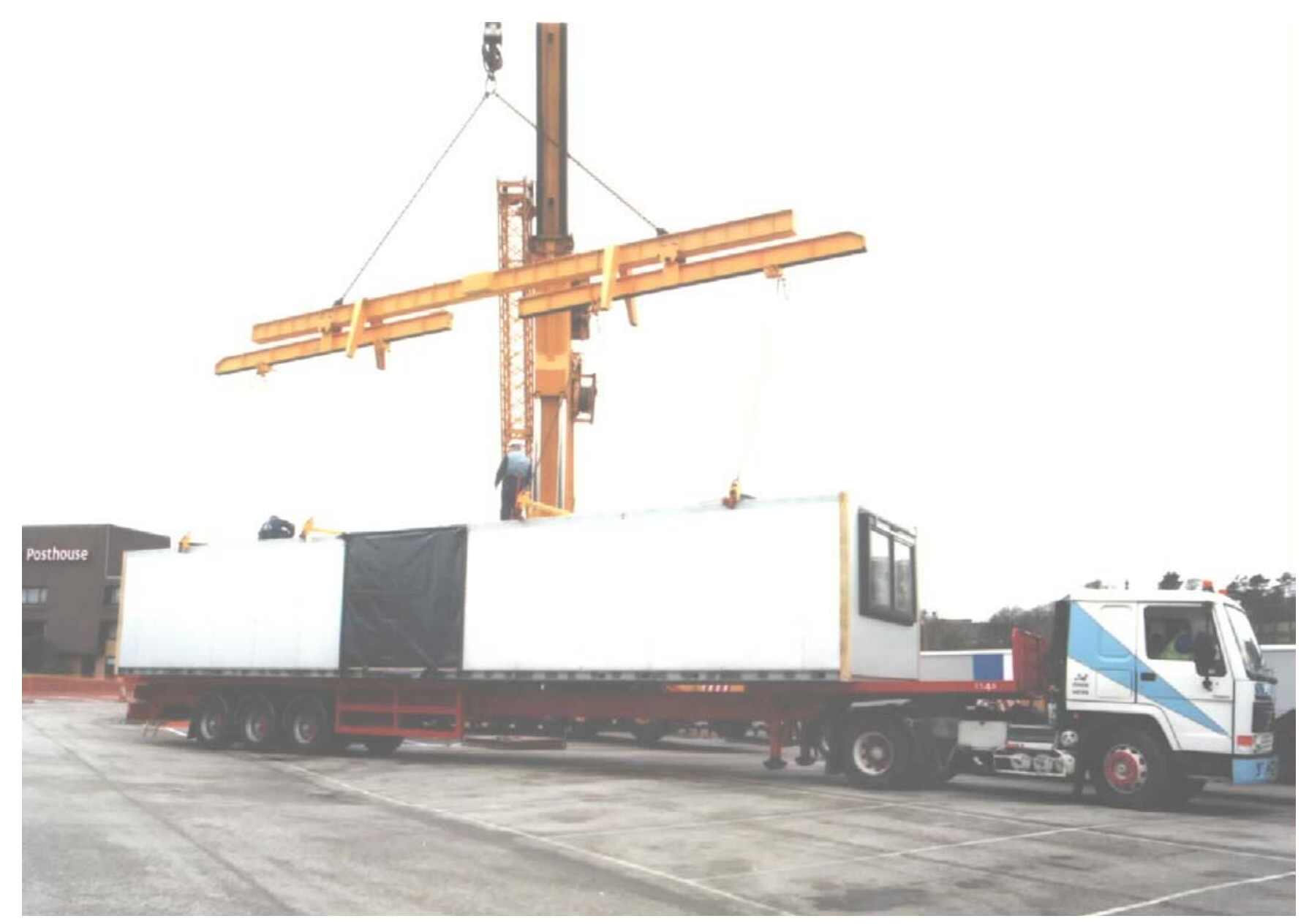


Figure 5

Volumetric pre-assembly - Installation of steel framed toilet unit in a restricted-space refurbishment project (inset: toilet internals completed off-site)

Courtesy Struik and Hamerslag International bv.

\section{Caption:}

These volumetric units are installed within a structural frame (in this case as part of a refurbishment project). The units are fully finished internally as shown in the inset. After installation the units are connected to the services supplies and then finished externally, usually with dry-lined partitions.

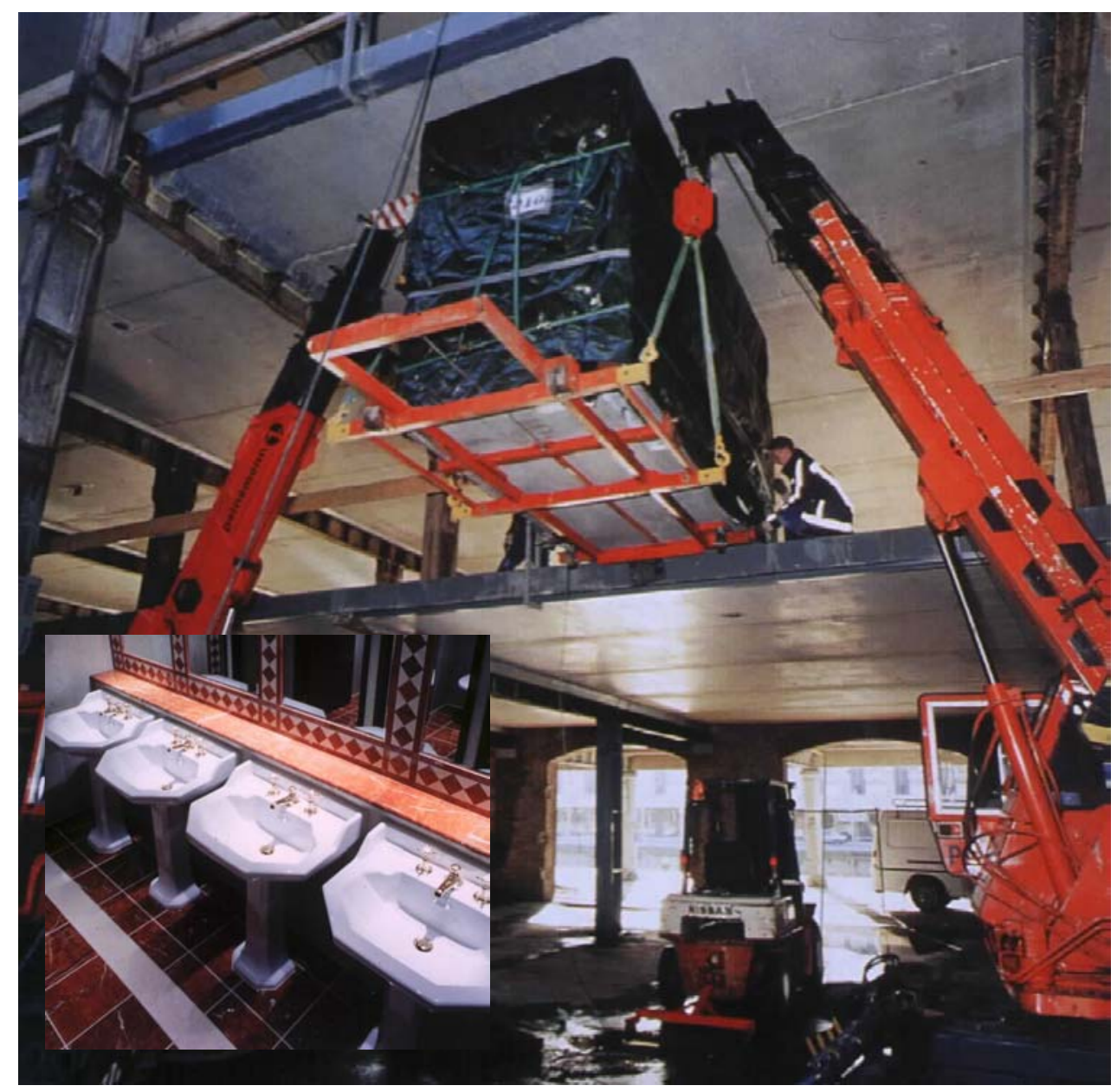


Figure 6

Volumetric pre-assembly - Installation of precast concrete shower room unit

Courtesy of Amec

\section{Caption:}

These precast concrete units are completed internally including all services, fittings and finishes - after installation within the building the outside of the unit is finished to match the internal decoration scheme for the building.

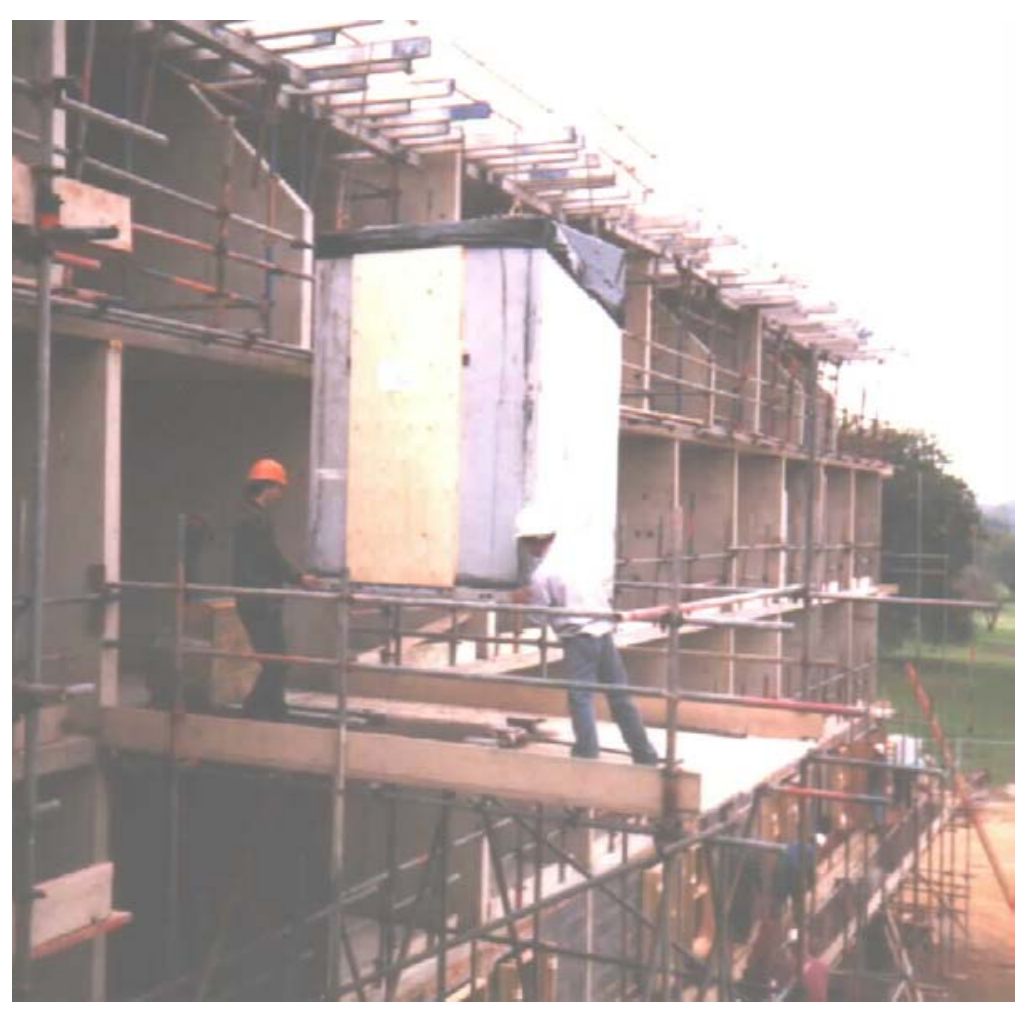


Figure $7 \quad$ Non-volumetric pre-assembly (planar) - Precast concrete cladding panel

Courtesy of Trent Concrete Ltd.

\section{Caption:}

These precast concrete panels are finished externally in the factory. Following installation windows are added along with internal finishes (dry-lined partition in this case). It is not uncommon for windows to be added off-site. Outside the UK, where an internal concrete finish is often acceptable composite panels incorporating insulation and the internal finished surface are often used.

Panellised aluminium and glass cladding units are also used for commercial developments.

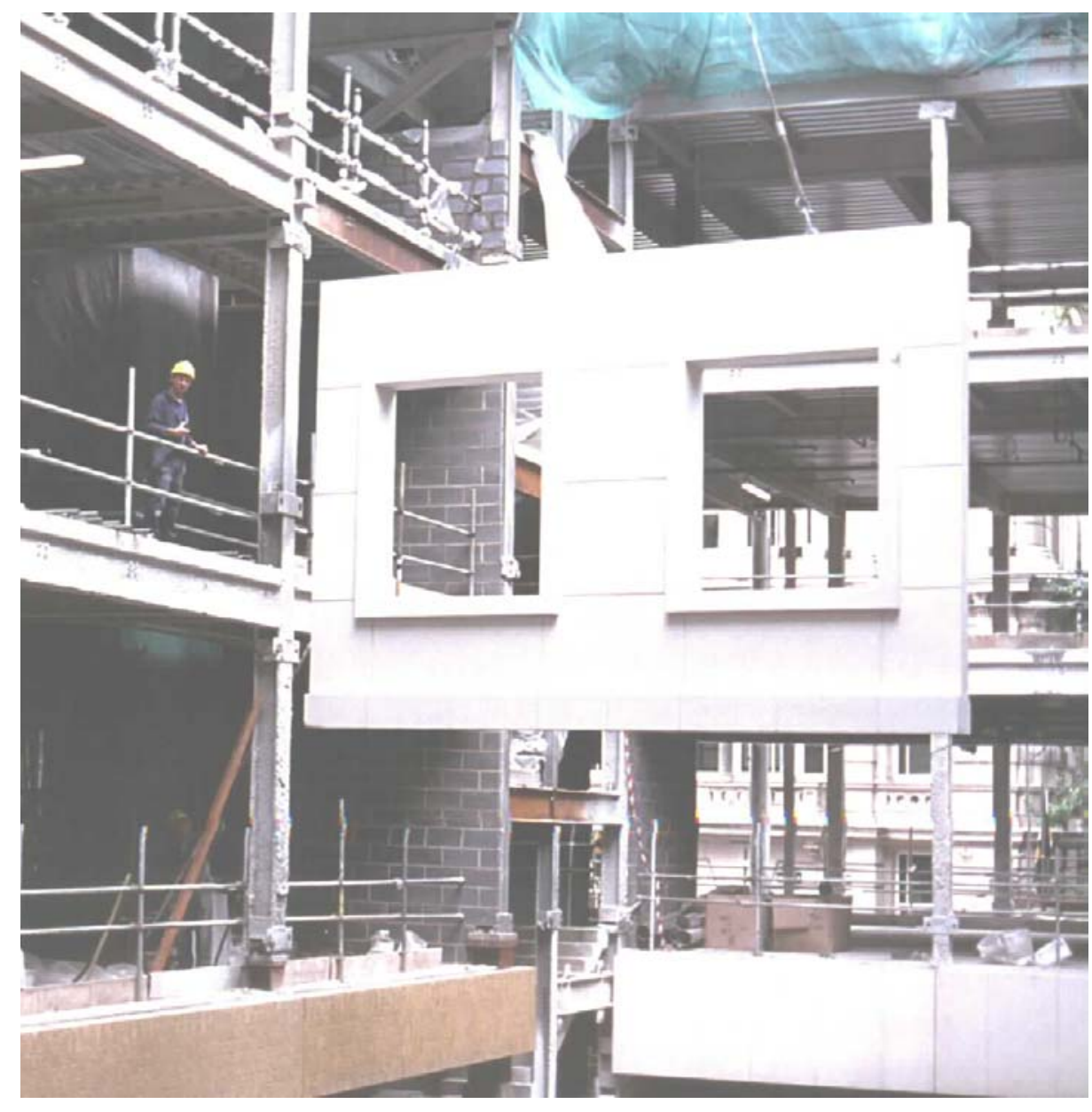


Figure 8

Non-volumetric pre-assembly (complex) - Factory handling test of building services module for office ceiling zone

Courtesy of Crown House Engineering

\section{Caption}

This application incorporates all of the fully commissioned above ceiling services for a commercial building. Further developments have also included the supports for the ceiling grid. After installation the various services are connected and final testing completed.

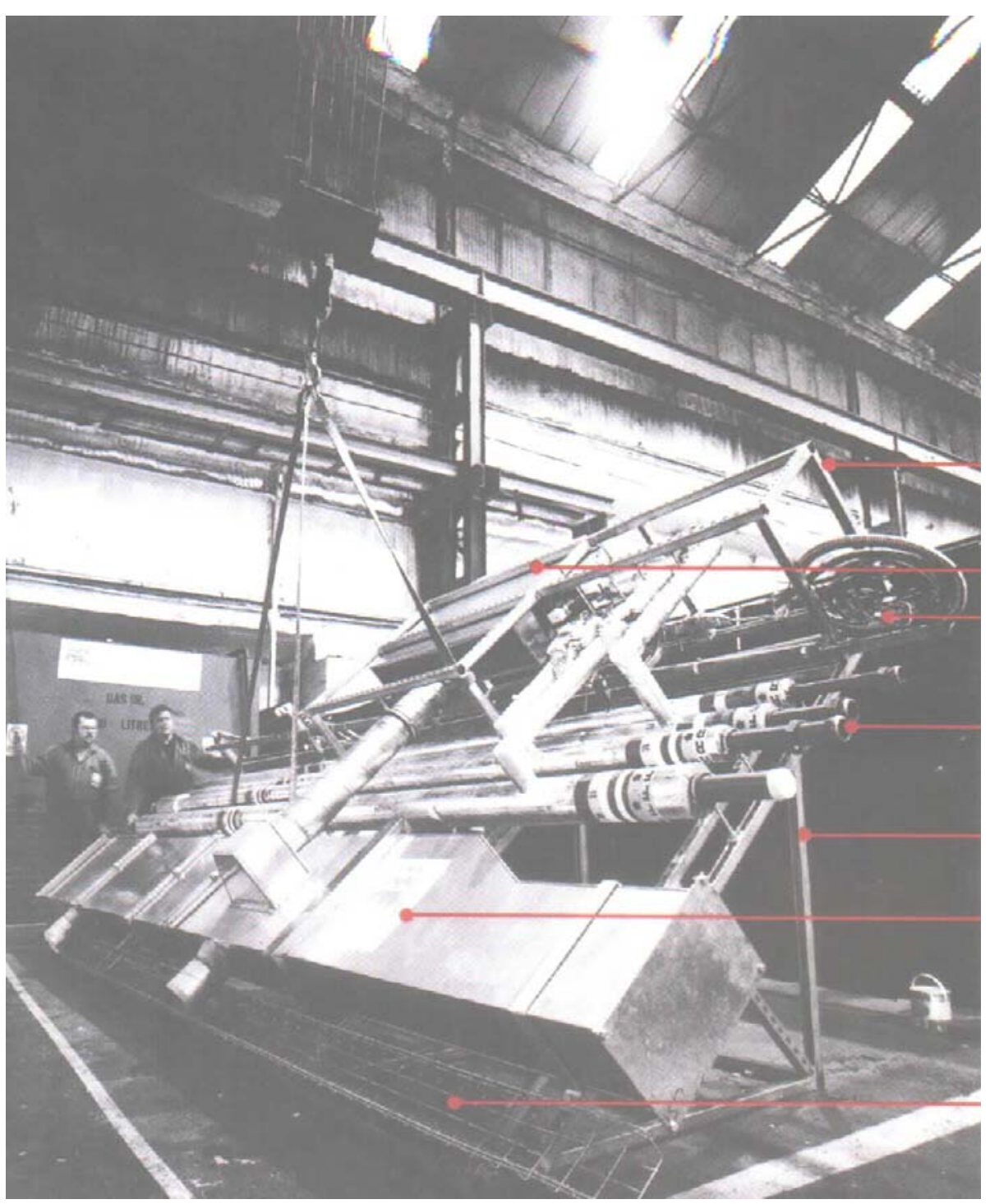


Figure 9

Non-volumetric pre-assembly (complex) - Installation of precast concrete bridge caissons

Courtesy of Laing

\section{Caption:}

This civil engineering application illustrates the size of units that can be manufactured and the handling

logistics that are necessary. In this case the units were made at a specially build manufacturing facility in the vicinity of the bridge.

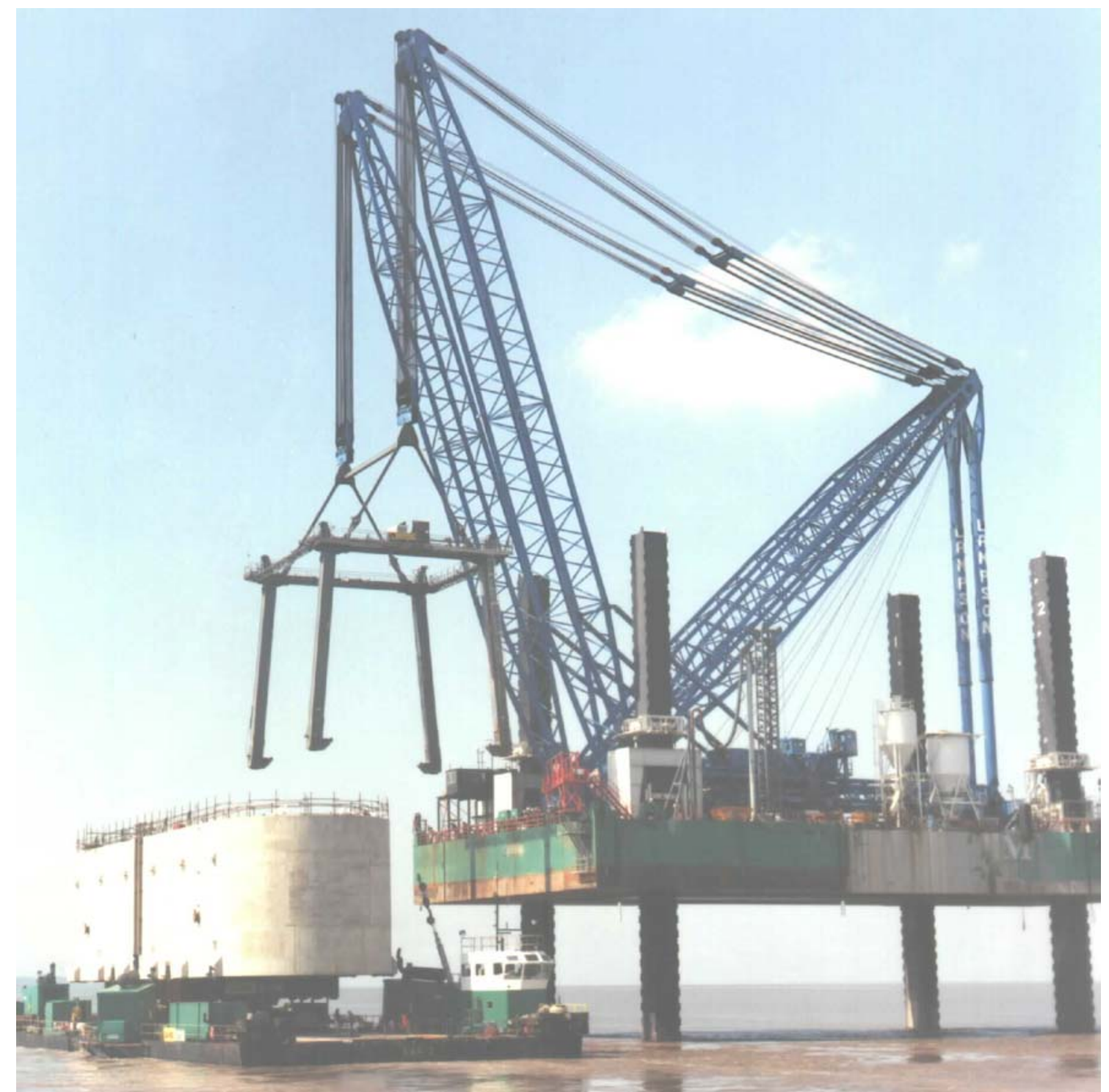


Figure 10 Breakdown of companies interviewed by construction market category

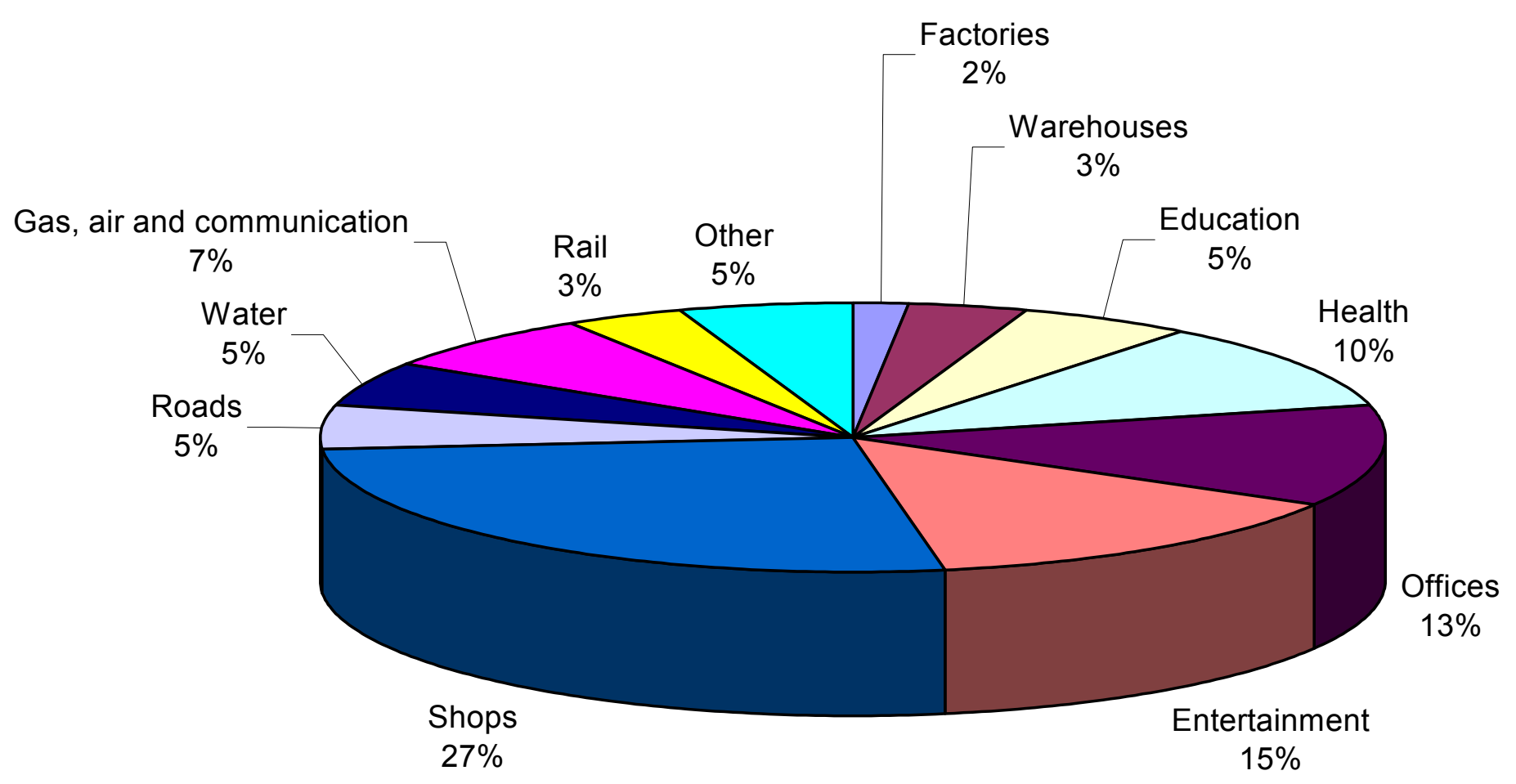




\section{Figure 11 Clients views on the benefits of preassembly}

(117 responses)

Less time on site - speed of construction 26

Speed of delivery - of product 5

Less time spent on commissioning 3

Guaranteed delivery, more certainty over the

programme, reduced management time 4

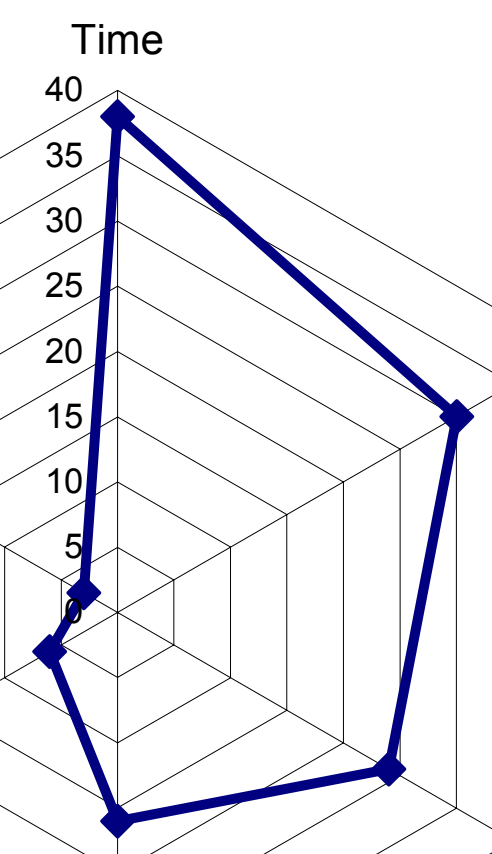

Higher quality - on site and from factory 17 Product tried and tested in factory 3

Greater consistency - more reproducible 5

More control of quality, consistent standards 5

gramme driven centrally 1

Simplifies construction process 1

Allows systems to be measured 1

\section{People}

Fewer people on site 1

People know how to use products 1

Lack of skilled labour 1

Production off-site is independent of local labour issues 1

Includes less snagging, more success at interfaces, less site disruption, reducing the use of wet trades, removing difficult operations off-site, products work first time, and

Productivity

Lower cost 12

Lower preliminary costs 2

Increased certainty, less risk 3

Increases added value 2

Lower overheads, less on-site damage,

less wastage 5

\section{Cost}




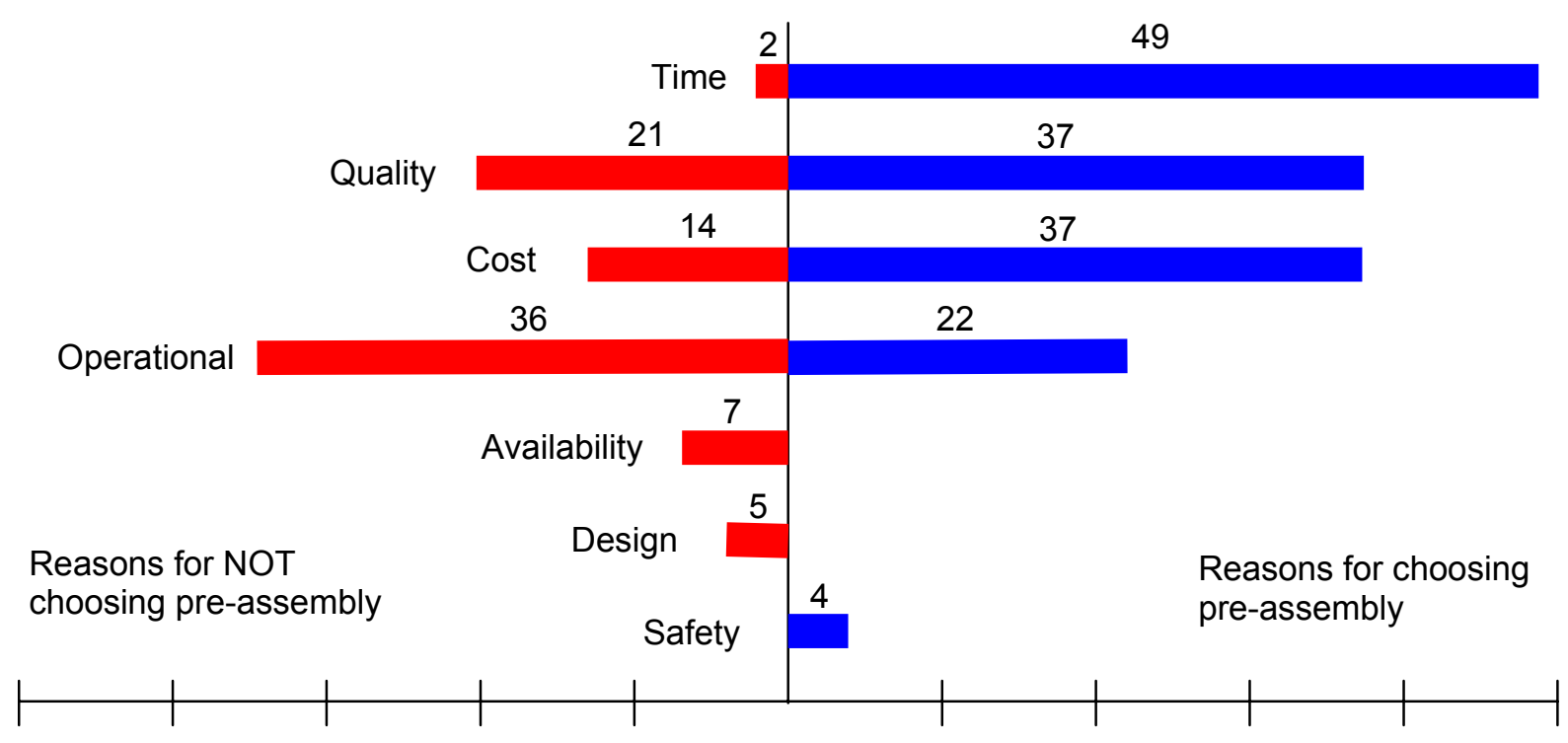

Figure 12 Reasons for using, or not using pre-assembly

(Prompted answers - number of times mentioned) 
Figure 13 Interviewees timing for preassembly (\% of 39 responses)

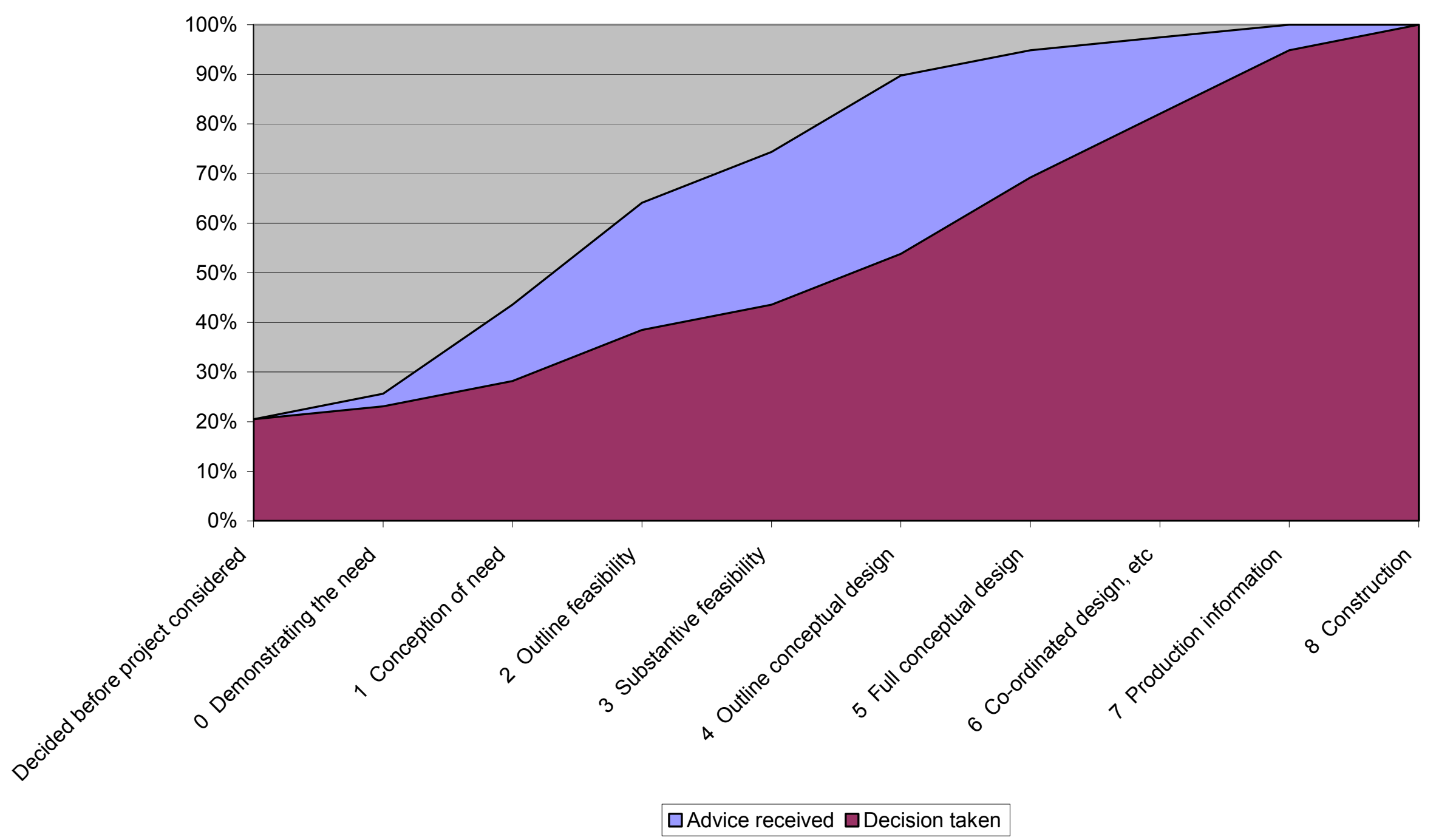


Figure 14 CIRIA optimised decision timing for preassembly

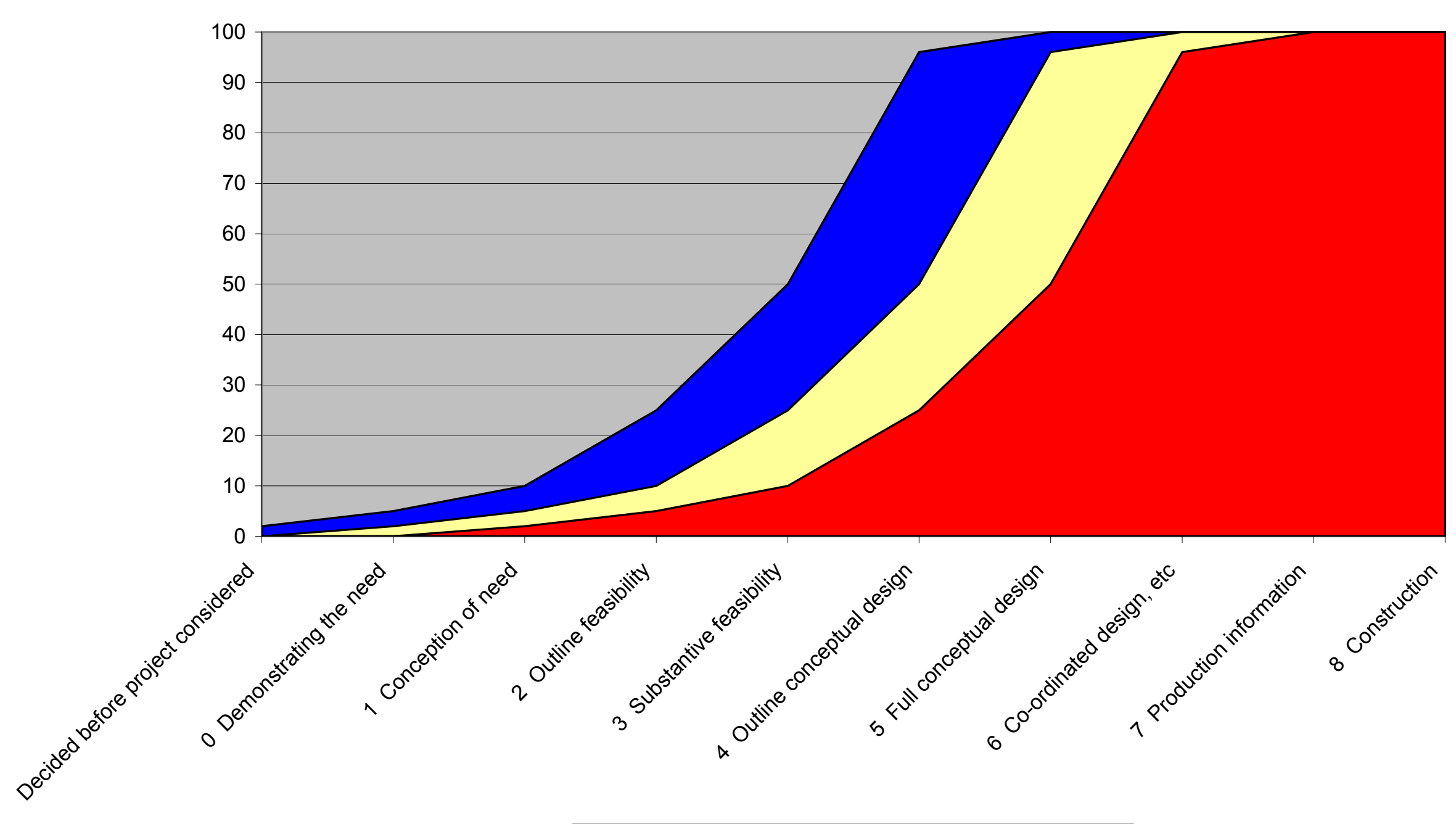

口 Modular building $\square$ Volumetric PA $\square$ Non-volumetric PA 


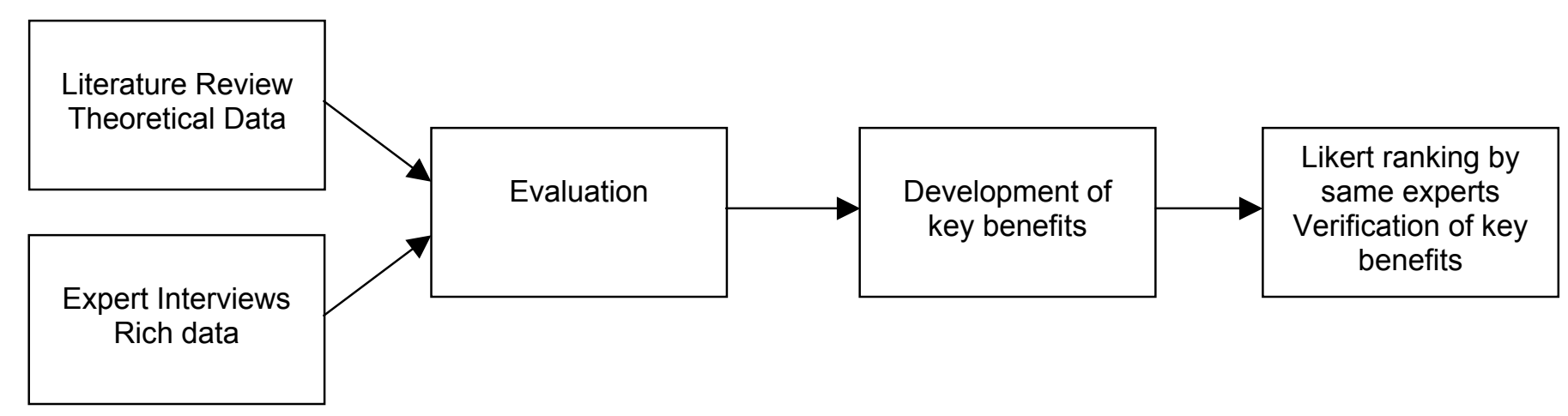

Figure 15

Validation method 
Figure 16 - Verified ratings of benefits from preassembly

(Standard deviation shown on bars)

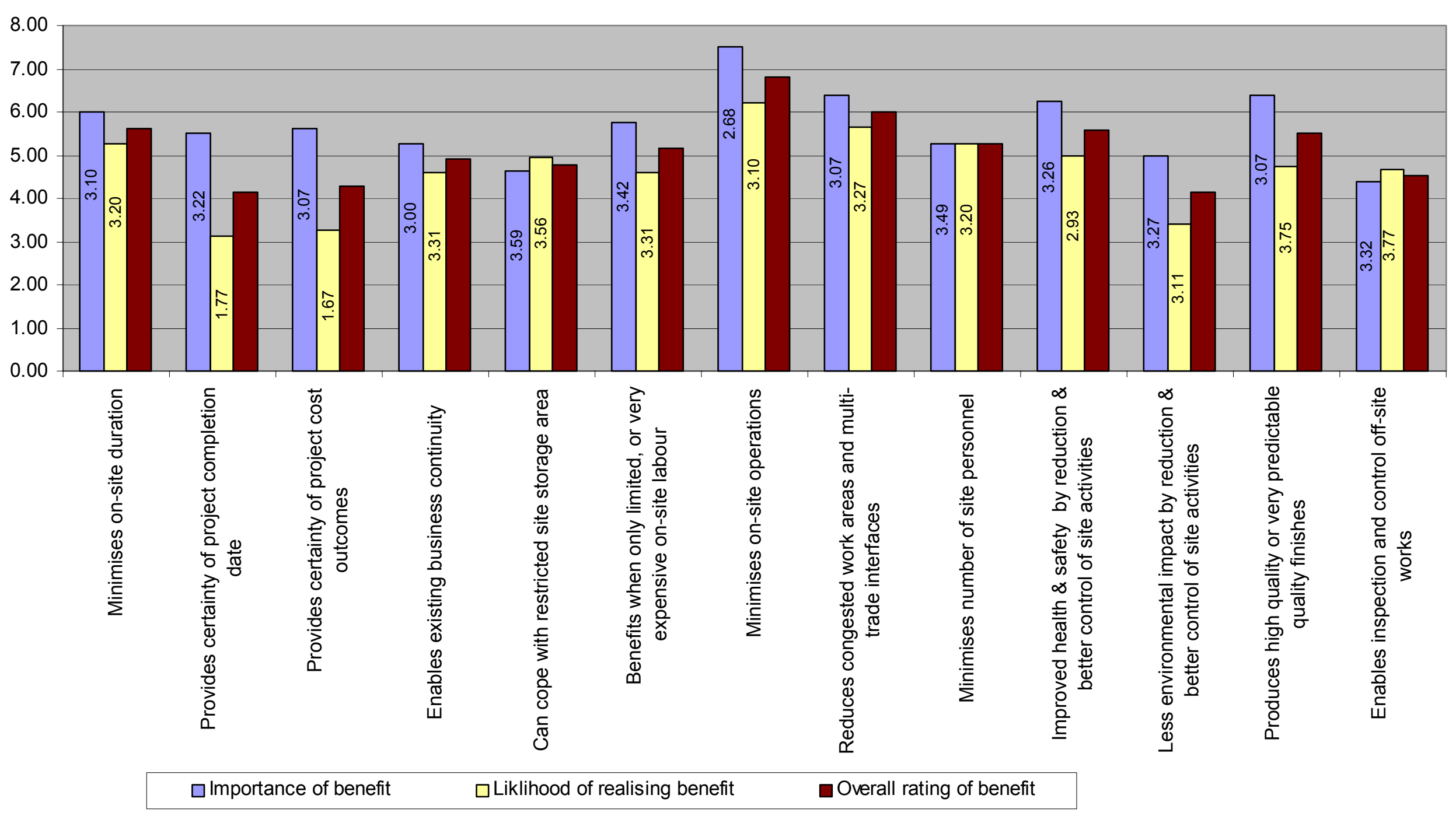


Figure 17 - Verified rating of key requirements to realise benefits from preassembly (Standard deviations shown on bars)

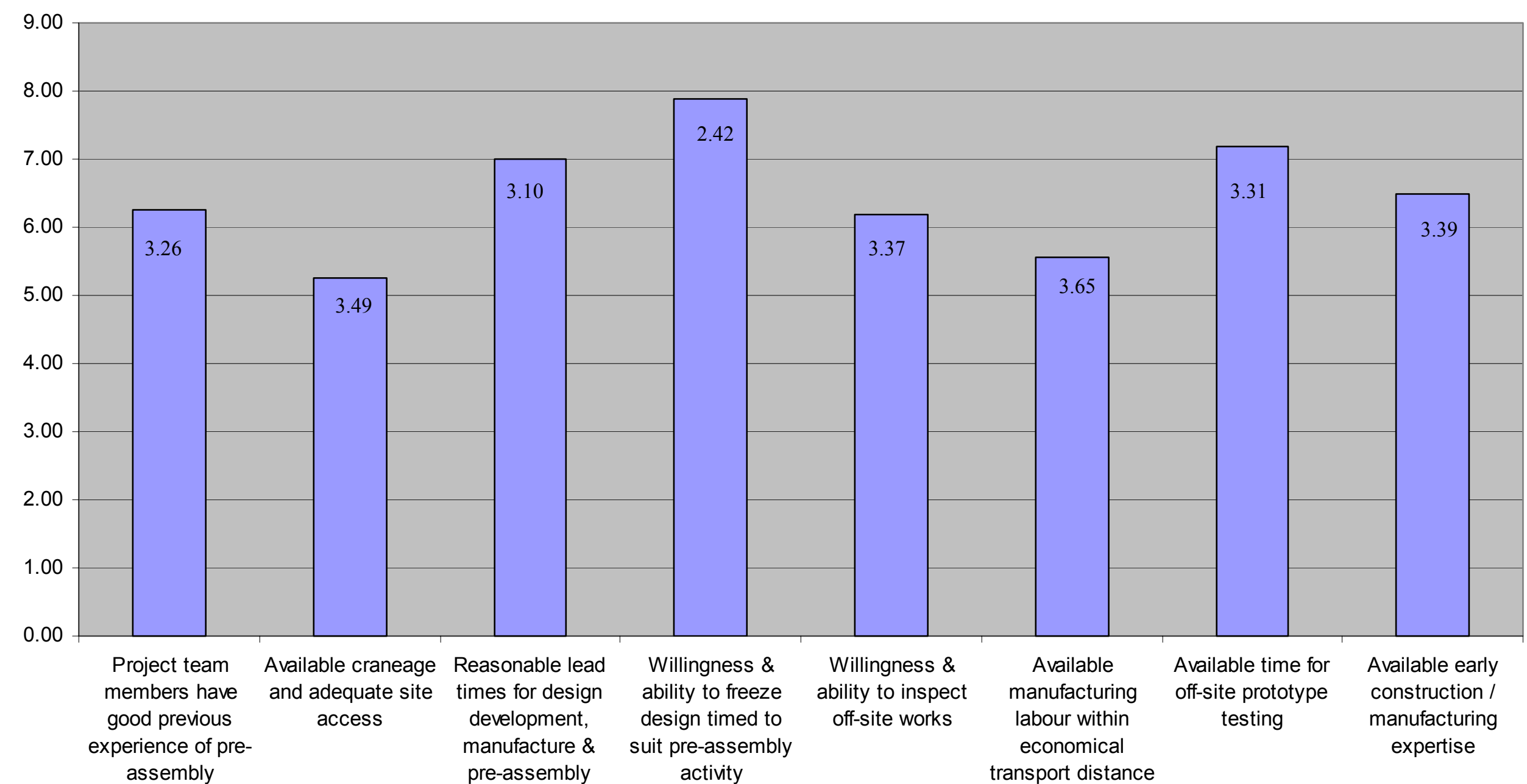

